\title{
Misha or Mihailik: A Sociolinguistic View on the Ukrainization of Russian Proper Names in Modern Ukraine
}

\author{
NATALIA KNOBLOCK (D) \\ English Department, Saginaw Valley State University, University Center, \\ MI, USA
}

This article focuses on linguistic identity and ideology through analysis of the attitudes of Russian-speaking Ukrainians toward the Ukrainization of traditionally Russian proper names (personal names and toponyms). It summarizes the results of a survey conducted among Ukrainian refugees to Russia, which gauged whether this policy contributes to the alleged alienation of the Russian-speaking population of Ukraine from current political and social developments in the country. The results of the study appear to support the importance of preserving the Russian proper names. Their Ukrainization seems to cause some resentment, especially when it affects people's own names and the names of their children.

KEYWORDS Language rights, ideology, personal names, toponyms, Ukraine, Russia, conflict, refugees

\section{Introduction}

The history of the interaction between the Russian and Ukrainian languages has been complex and difficult. ${ }^{\mathrm{I}}$ For many years, Ukraine was a multilingual, multicultural territory where two major and several minor languages coexisted, but the repression of the Ukrainian language during the times of the Russian Empire and the Soviet Union contributed to efforts to elevate its role after Ukraine achieved independence in the early I990s. ${ }^{2}$ Since then, the status of the Ukrainian language has risen considerably, with the majority of public events, government business, and secondary and post-secondary instruction conducted in it Bilaniuk and Melnyk 2008). A reversal of linguistic ideology occurred: from a minority language, often considered inferior, Ukrainian has become the only official language, 
while Russian has been moving to a position of minority and lower prestige (Friedman 2009). Diglossia is still present but is no longer welcome in Ukrainian society (A'Beckett 20I3).

The struggle to elevate the status of the Ukrainian language is not without problems (A'Beckett 20I3). A prominent nationalist politician famously caused an uproar in 20I0, when during a televised visit to a day-care center, she told preschoolers that they should switch their Russian-sounding names to Ukrainian versions or "pack their suitcases and leave for Moscovia [Russia]". She declared that parents' preference for the diminutive Misha over Mihailik was "a catastrophe" She then presented the children with a chart of "right" (Ukrainian) and "wrong” (Russian) versions of common names (Politota [Политота] 20I4). ${ }^{3}$

While this example is extreme, renaming people is a routine practice in Ukraine. Since gaining independence, the Ukrainian authorities have, among other actions, implemented standardization of personal names according to Ukrainian language conventions regardless of the linguistic background of the person being named. This policy has affected not only newborn children, but also adults whose documents have been reissued. The change was likewise applied to toponyms, which were adjusted to conform with Ukrainian spelling and pronunciation conventions. Numerous additional changes were recently implemented after the state legislature's decision to "decommunize" the country. For example, the city of Kirovograd became Kropyunytsky, the name choice supported by $2.8 \%$ of its population (Interfax-Ukraine 20I 5), and Dnepropetrovsk was converted to Dnipro without polling its population of over a million inhabitants.

Dissenting voices are rare in official discourse, but they are present in social networks. For example, when the breakaway city of Donetsk apparently changed the spelling of the city's welcome sign from Ukrainian back to Russian in April 20I 5, a post about it on the social network OK.ru attracted congratulatory comments. The post "Donetsk is spelled without the soft sign" was accompanied by "before" and "after" photographs. The elimination of the letter "soft sign", which is obligatory in Ukrainian but unnecessary in Russian, appeared to hold significance for people who engaged in the online discussion. One of the commenters in that thread revealed her attitude toward this issue:

Donetsk would be called Donetsk even in Africa. In no language do names translate. Only in Ukraine can my son Nikita be called [taunted] Mykyta. I named him Nikita. Why on earth should he be Mykyta? Same with Donetsk. [Russian with code-switching to Ukrainian in original]

The poster's sentiment can be interpreted as irritation that her right as a mother to determine her son's name was disregarded by the authorities, and her power over naming her own child was appropriated by them.

Besides the general issues of linguistic ideology such as prestige and preferences, the process of Ukrainization also raises the question of the judiciousness of its implementation. Occasionally, these interventions cause problems, and, in 
extreme cases, this can lead to such situations as described by another commenter on the same thread. In this instance, the last name with the root related to the Russian word krasnyj (red) was translated and changed completely to reflect the pronunciation of the Ukrainian word for red' červonyj:

My niece, she went to change her passport, her last name is Krasnova, she receives her passport, and it has Natalia Chervona instead of Natalya Krasnova (first name was also changed). When asked how so ... ? The passport lady said that this is how the name sounds in the "national language". This illiterate fool does not even know that proper nouns, last names and geographical names are not supposed to be translated. ... If the powers that be knew grammar, then Donetsk would never have been Donetsbk, and Nikolaev would never have been Mykolaev. [Russian with code-switching to Ukrainian in original]

Language (specifically, Russian), its value for eastern Ukrainians, and the right to continue using it in official and private situations appear to be fairly regular themes in the social networks consulted for this research. However, it would be unwise to base any serious conclusions on these posts because they may or may not be representative of the prevailing frame of mind of the eastern Ukrainian population. It is not possible to assess whether the information is true and, for example, whether the above-mentioned person who claims to be from Donetsk does, in fact, reside in that city. Furthermore, social networks can be influenced by a relatively small number of activists who promote their agendas, attract people of similar views, and distort the overall picture. Still, the study of unofficial language ideology in a time of rapid and radical social change is important, and attention to the practical aspects of the Ukrainization of Russian personal names and toponyms is worthy of consideration. ${ }^{4}$

\section{Theoretical background}

Proper nouns and personal names have been studied in onomastics, semiotics, and the philosophy of language, and have been widely accepted as essential to people's sense of self and sense of identity (Le Page and Tabouret-Keller I985). In addition to the right to speak and receive an education in one's native tongue (Skutnabb-Kangas 2000), the ability to determine one's own name has been described as one of the basic human rights (Jernudd 2010).

Since "[1]imits on the choice of one's own name are de facto limits on the individual's zone of privacy', international law protects this choice as a part of the privacy clause of Article 8 of the Convention for Protection of Human Rights and Basic Freedoms (Gross I996, 269). Recognizing the importance of the use of names according to an individual's first language, the Organization for Security and Co-operation in Europe (OSCE I998, 5) recommends that "[p]ersons belonging to national minorities have the right to use their personal names in their own language according to their traditions and linguistic systems. These shall be given official recognition and be used by the public authorities". This is 
unsurprising since language maintains strong associations with national and ethnic identity and a person's name "is a primary element in his biography" (Giddens I99I, 55).

Theoretically, linguistic human rights are protected by international law, such as the Oslo Recommendations of the OSCE or the International Covenant on Civil and Political Rights (ICCPR), which has been in force since I976. Article I of the ICCPR states that peoples have the right to "freely pursue their economic, social and cultural development" (Joseph and Castan 2013, I 53), and Article 27 guarantees ethnic, religious, or linguistic minorities' right "to enjoy their own culture, to profess and practise their own religion, or to use their own language" (Joseph and Castan 2013,832), which may be extended to mean that a person should be able to use his or her name in accordance with the phonetic and spelling rules of that person's first language.

Practically, however, even when someone wins the legal fight for his or her name to be spelled according to the linguistic norms of his or her first language, the ruling may still be ignored by national authorities. In the case Raibman vs. Latvia, for example, the Human Rights Committee ruled that the forceful change of Leonid Raibman's first and last name to Leonids Raibmans by the Latvian government was an unnecessarily intrusive measure. Citing Article I 7 of the ICCPR as encompassing the right to choose and change one's own name, the committee considered the modification unreasonable and amounting to arbitrary interference with Mr Raihman's privacy. Nevertheless, Latvian officials ignored the ruling and refused to change the documents back to the spelling he preferred (Joseph and Castan 2013).

In relation to the importance of preserving toponyms in minority languages, the Oslo Recommendations states: "public authorities shall make provision for the display, also in the minority language, of local names, street names and other topographical indications intended for the public" (OSCE I998, 5). However, these recommendations have also been snubbed by the authorities, and cities and towns have been named and renamed without regard to the population's opinion, as exemplified by the Hungarian city of Kolozsvár which was renamed three times after being ceded to Romania (Kontra I999).

While there are circumstances under which an adjustment to another language's norms might be necessary, the adjustment of personal names to comply with the linguistic norms of a society should be encouraged but should not be enforced (Jernudd 20I0). As Jernudd explains, taking issue with a person's name invites confrontation and creates potential for conflict. He argues that demanding a change of a person's name or blocking registration of his/her chosen name "can be construed as violations of a human right" and asserts that involuntary changes of names are dangerous and can threaten the stability of a society rather than ensure it (Jernudd 2010, I29). This message is also developed by Kontra (I999, 28I), who explains that respecting people's linguistic traditions in naming is vital for a society's stability since losing that right unwillingly "causes human trauma and social conflict". Kontra argues that the denial or 
violation of linguistic human rights including "the right to use one's name, the traditional names of historic figures or regions" contributes to social unrest in Central and Eastern Europe and elsewhere (282).

In the context of Ukraine, the "monist" approach to Ukrainian nation-building, where a very exclusive list for defining qualities for a "real Ukrainian" (including speaking Ukrainian and avoiding the Russian language) is promoted, has also been credited with contributing to the current struggles in the country, and a case is made for accepting and promoting pluralistic diversity in Ukraine (Sakwa 20I6). This is especially important since both Russians and Ukrainians can be considered state-constituting ethnicities of Ukraine (Pogrebinskiy 2015), and since "Ukraine is, at its heart, bilingual and bicultural" (Petro 201 5, 33).

The situation with Russian and Ukrainian identity and language usage is complex (Polese and Wylegala 2008; Wilson 2002), and the terms "native tongue", "first language", "preferred language", etc. in Ukraine have been politicized and are extremely sensitive. It does not help that the terms "native tongue" or "mother tongue" are complicated by the various meanings afforded to them (Skutnabb-Kangas I98I). Caution has been recommended in their application in the context of Ukraine because interviewees, for example, may list Ukrainian as their native language but still prefer Russian for the interview (Andreenkova 20I4; Gradirovski and Esipova 2008), which might reflect the official policy of declaring Ukrainian the native language of every Ukrainian citizen and its use "the duty of a patriot" (Friedman 2009, 346). Consequently, these terms have been avoided altogether in the survey.

This research project sought answers to the following questions:

I. Did the Ukrainization of Russian proper names matter to Russianspeaking Ukrainians polled for this investigation?

2. What was the attitude toward the Ukrainization of traditionally Russian proper names in the group polled?

\section{Methodology}

The study was conducted in the summer of 20I 5 , when many Ukrainian citizens had moved to the Russian Federation asking for temporary asylum, refugee status, or sought Russian citizenship. About 3,000 Ukrainian refugees were living in Tambov, Russia and the surrounding area. The locations for data collection were identified by word-of-mouth, as refugees were often placed compactly in hotels, out-of-town resorts, decommissioned schools, college dormitories, and similar sites, and their location was general knowledge. Participants were recruited by explaining the nature and purpose of the study, and they received no compensation for participation. Only subjects 18 years of age or older were invited to participate. They signed informed consent forms and filled out paper questionnaires with multiple choice answers. 
The questions were about the use of Ukrainian and Russian proper names, whether their Ukrainization created any inconvenience, and whether preserving the Russian versions of their names were of any importance to them. The questionnaires also collected some demographic data, such as age, the language used in several spheres (work, home, communication with friends, etc.), place of residence, and whether the respondents were planning to stay in the Russian Federation or return to Ukraine. Data on the participants' legal situation was not collected as many might have been wary of persons questioning their legal status after fleeing their home country, legally or otherwise. Such questions might have unnecessarily discouraged otherwise qualified participants from completing the survey, especially if they immigrated without being granted asylum or a formal refugee status. All of them escaped from war in their home country, sought refuge in the Russian Federation, and were living in temporary housing provided by the Russian government at the time of data collection.

Altogether, 92 questionnaires were collected. Participants came from 28 different eastern Ukrainian cities and had escaped to Russia after the beginning of military actions in their territories. The most numerous age group was I $8-29$ years of age $(33.69 \% ; n=3 \mathrm{I})$ as it was often parents with children who fled the war zone; the least numerous was the $60-69$ group $(7.60 \% ; n=7)$, no one circled the option "70 and over" (0.00\%;n=0); and there were two questionnaires with no response to this question $(2.17 \% ; n=2)$.

\section{Results}

\section{Respondents' names}

The first section of the survey focused on the respondents' own names. Out of 92 responses, $56(60.86 \%)$ stated that the Russian and Ukrainian versions of their names were different even though the differences are often minimal - for example, the letters " $и$ " in Russian and " $i$ " in Ukrainian denote a very similar sound, or the letter " $\Gamma$ " looks identical in both alphabets but denotes slightly different sounds.

The part of the questionnaire about predominant language use in different communication spheres was unexpectedly uninteresting. Almost all of the participants reported using the Russian versions of their names at work, at home, with friends, and in official situations, and most specified that it did not cause any problems. Out of the 92 questionnaires, only nine $(9.78 \%)$ mentioned the use of the Ukrainian language, usually in official situations (while the other three domains were still conducted in Russian). Only five of those nine people $(55.55 \%)$ reported inconvenience caused by this use of the Ukrainian language, with one claiming that it caused "much" trouble, and four suggesting that it caused "some" trouble.

Predictably, 94.56\% $(n=87)$ of the people stated that they preferred the Russian version of their name, and the remaining five participants said that it 
TABLE 1

PREFERENCE OF RUSSIAN OR UKRAINIAN NAMES

\begin{tabular}{lcccc}
\hline & Prefer Russian & No Preference & Prefer Ukrainian & No Response \\
\hline $\begin{array}{l}\text { Respondents' own names } \\
\text { when different in Russ. and Ukr. }\end{array}$ & 48 & 7 & 0 & 1 \\
$\begin{array}{l}(n=56) \\
\text { Respondents' own names }\end{array}$ & 20 & & & \\
when same $(n=36)$ & & 12 & 0 & 4 \\
Children's names & 75 & 7 & 0 & 10 \\
City names preference & 75 & 17 & 0 & 0 \\
Street name preference & 76 & 15 & 0 & 1 \\
\hline
\end{tabular}

made no difference to them. No one preferred the Ukrainian spelling or pronunciation. The majority of the $56(60.86 \%)$ people who reported that their names differed in Russian and Ukrainian preferred the Russian version of their name $(85.7 \mathrm{I} \% ; n=48)$. Seven (I $2.5 \%)$ participants circled "no preference", and one person $(\mathrm{I} .78 \%)$ left the line blank. No one reported a preference for the Ukrainian spelling or pronunciation (see Table I).

Somewhat surprisingly, the group whose names did not differ in the two languages (36 respondents out of $92 ; 39.13 \%$ ) still reported that they preferred the Russian versions of their names. Only four (I I.I I \%) participants left the question blank, which was expected since the respondents reported that their names were identical in both languages, while $20(2 \mathrm{I} .73 \%)$ participants circled the option of Russian. The participants in this group were more likely to circle the "no preference" option $(33.33 \%$; I 2 out of 36$)$ than the group whose names differed (I2.5\%; 7 out of 56), but still none indicated a preference for the Ukrainian spelling and pronunciation (see Table I).

Three respondents $(3.26 \%)$ were probably confused as they answered "no" to the question of whether their named differed in Russian and Ukrainian, but then claimed that their names were changed to Ukrainian by the authorities. One of them even added that the change was voluntary, and two mentioned that it happened when they received their passports. It is difficult to know for sure, but those were probably cases when the differences were minimal or when the pronunciation was the same, but the spelling differed slightly. These questionnaires were still counted as reporting no preference between Russian and Ukrainian because that is what the respondents indicated.

When asked whether their names were recorded according to the Russian or Ukrainian norms in their official documents, $32.14 \%(n=18)$ respondents of the 56 whose names differed in Russian and Ukrainian stated that the Russian spelling of their name was preserved in official documents, one person circled both "yes" and "no" (possibly referring to partial changes), one left the line blank, and $64.28 \%(n=36)$ reported that their name was written according to Ukrainian conventions (see Table 2). Out of the 36 people whose names were changed according to Ukrainian pronunciation and spelling norms, 
TABLE 2

PERSONAL NAMES RECORDED

\begin{tabular}{|c|c|c|c|}
\hline Russian Version & Ukrainian Version & No Response & Both Yes and No \\
\hline 18 & 36 & 1 & 1 \\
\hline
\end{tabular}

TABLE 3

IMPORTANCE OF NAME CHANGE FROM RUSSIAN TO UKRAINIAN

\begin{tabular}{llllll}
\hline \multicolumn{2}{l}{ Name change mattered $(n=36)$} \\
\hline Very Much & Somewhat & Neither Yes/No & A Little & No & No Response \\
\hline 9 & 9 & 6 & 2 & 9 & 1
\end{tabular}

TABLE 4

RESPONDENTS' PREFERENCE FOR THEIR NAME TO REFLECT RUSSIAN PRONUNCIATION

\begin{tabular}{lccc}
\hline Of the respondents whose names were changed $(n=36)$ & \\
\hline Of Course & Maybe & Absolutely Not & I Don't Know \\
\hline 23 & 4 & 6 & 3
\end{tabular}

6I.I I \% $(n=22)$ respondents left the line asking when and how that change occurred blank. However, one respondent added that it happened "during the breakup of the Soviet Union", and four explained that it was done when they received their passports (as required at I4 years of age to replace the birth certificate). Two people said that the change was "voluntary" and I 2 indicated that it was "involuntary", with one person adding "without my knowledge".

With regard to whether the name changes mattered to those whose names exhibited differences, nine $(25 \%)$ out of 36 respondents indicated that it mattered "very much", nine (25\%) circled "somewhat", six (I6.67\%) selected "neither yes nor no", 2 (5.55\%) chose "a little", nine (25\%) replied "no", and one person $(2.77 \%)$ left the form blank for this question (see Table 3 ).

Over half of the participants whose names were changed $(n=36)$ would have preferred the spelling of their name to reflect the Russian pronunciation ( 23 out of $36 ; 63.88 \%$ ): four (I I.I I \%) marked "maybe", three (8.33\%) chose "I don't know", and six ( $16.67 \%)$ replied "absolutely not" (see Table 4$)$.

\section{Children's names}

The next section of the survey addressed the names of the respondents' children and the parents' sentiments regarding their Ukrainization. They were asked whether the Russian and the Ukrainian versions of their children's names were 
TABLE 5

PARENTS' ABILITY TO CHOOSE SPELLING OF CHILDREN'S NAMES

\begin{tabular}{lccc}
\hline All respondents $(n=92)$ & & \\
\hline No Choice Offered & Choice Offered & Picked Both Responses & No Response/ No Children \\
\hline 69 & 10 & 1 & 12 \\
\hline
\end{tabular}

different, which version they preferred, whether they were given a choice to record their children's names according to their preference, and whether a lack of choice caused any negative emotions.

The majority of the 92 respondents $(8 \mathrm{I} .53 \% ; n=75)$ indicated that they preferred the Russian spelling and pronunciation of their children's names to the Ukrainian, while $7.60 \%(n=7)$ reported no preference, and $10.87 \%(n=10)$ people had no response because they were childless and the question did not apply to them (see Table I). Of those who had children, I3.33\% $(n=\mathrm{I} 0)$ stated that they were offered a choice whether to record the Russian or the Ukrainian version of their children's names. One questionnaire contained contradictory information (circled both "yes" and "no"), and 69 participants (92\%) reported that they had no choice when the time came to receive their children's birth certificates, and their children were given Ukrainian names despite their parents calling them by Russian names. Twelve respondents left these options blank or wrote "no children" (see Table 5).

Of the 69 parents who reported having no choice while recording their children's names, eleven (I5.94\%) said they were "very much" bothered by the arrangement when the city clerks recorded their children's names in the Ukrainian variants rather than the Russian without consulting the parents first. Twenty parents $(28.98 \%)$ reported having "some" negative feelings caused by the situation. The number of people who appear to be irritated by this practice is much higher among the parents who reported that their children's names differed in Russian and Ukrainian. Of the 36 parents who had no choice about their children's names AND whose children's names differed in their documents from what their families called them, ro $(27.78 \%)$ reported strong negative feelings, I7 $(47.22 \%)$ were somewhat bothered by it, one person $(2.7 \%)$ circled "neither yes nor no", one (2.7\%) chose "little", and seven (19.44\%) reported having no negative emotion (see Table 6).

\section{City names}

The city names section asked what version of their city's name the participants preferred, whether their city's name was changed from their Russian to the Ukrainian variant, whether such change caused any inconvenience, and whether it caused any negative emotions for the participants. 
TABLE 6

NEGATIVE EMOTIONAL RESPONSE

\begin{tabular}{|c|c|c|c|c|c|c|}
\hline & Very Much & Some & Neutral & Little & None & No response \\
\hline $\begin{array}{l}\text { Lack of choice in children's names } \\
\text { (when names differ in Russ. and } \\
\text { Ukr.) }(n=36)\end{array}$ & 10 & 17 & 1 & 1 & 7 & 0 \\
\hline $\begin{array}{l}\text { Hometowns/cities renamed } \\
(n=36)\end{array}$ & 7 & 11 & 4 & 1 & 12 & 1 \\
\hline $\begin{array}{l}\text { Hometowns/cities renamed AND } \\
\text { preference for Russ. }(n=29)\end{array}$ & 7 & 11 & 3 & 1 & 6 & 1 \\
\hline Streets renamed $(n=28)$ & 6 & 8 & 3 & 1 & 10 & 0 \\
\hline $\begin{array}{l}\text { Streets renamed AND preference } \\
\text { for Russ. }(n=23)\end{array}$ & 6 & 7 & 3 & 1 & 6 & 0 \\
\hline
\end{tabular}

TABLE 7

REPORTED INCONVENIENCE RESULTING FROM TOPONYM CHANGE

\begin{tabular}{|c|c|c|c|c|c|}
\hline & Very Much & Some & Neutral & Little & None \\
\hline Hometowns/cities renamed $(n=36)$ & 6 & 12 & 3 & 2 & 13 \\
\hline $\begin{array}{l}\text { Hometowns/cities renamed AND preference for } \\
\text { Russ. version }(n=29)\end{array}$ & 6 & 12 & 2 & 2 & 7 \\
\hline Streets renamed $(n=28)$ & 7 & 9 & 3 & 0 & 9 \\
\hline $\begin{array}{l}\text { Streets renamed AND preference for Russ. } \\
\text { version }(n=23)\end{array}$ & 7 & 8 & 3 & 0 & 5 \\
\hline
\end{tabular}

Out of the 92 respondents, $75(8 \mathrm{I} .53 \%)$ reported that they preferred the Russian version of their city's name, and I7 ( $18.47 \%$ ) people had no preference. Only 36 (39.13\%) out of 92 indicated that their city's name was changed from Russian to Ukrainian, with $54(58.70 \%)$ reporting that there had been no change and two $(2.17 \%)$ providing no answer.

In the group of those 36 people who lived through a city name change, only half claimed that it caused "much" or "some" inconvenience (six and twelve participants, respectively). Three people $(8.33 \%)$ marked "neither yes/no", two $(5.55 \%)$ selected "little", and I3 (36.I I \%) reported "no" trouble caused by this change. However, when this question is juxtaposed with the question of language preference, reported inconvenience/trouble become more noticeable. Out of the 29 people whose cities were renamed AND who preferred their Russian spelling and pronunciation, six $(20.69 \%)$ stated that it caused "much" inconvenience/trouble, I2 (4I.38\%) said "some", two (6.90\%) marked the "neither yes/no" option, two chose (6.90\%) "little", and seven (24.13\%) gave the "none" answer. Based on this data, it would seem that preference in the city's name may be related to the trouble caused by its renaming (see Table 7).

While answering the question whether the city's name change caused any negative emotions, seven (19.44\%) of the 36 whose cities were renamed reported "much" irritation, I I $(30.56 \%)$ reported "some", four (II.I I\%) people were indifferent with "neither yes/no", one $(2.78 \%)$ showed "little" negative 
emotion, I2 $(33.33 \%)$ said "none", and one $(2.78 \%)$ provided no answer. Again, if these responses are compared among the people whose cities were renamed AND who preferred the Russian version, the irritation appears more discernable. Of the 27 people in both categories, the seven $(25.92 \%)$ "much" and II $(40.74 \%)$ "some" responses remained the same, but the group who were not bothered by the change shrank somewhat. Three people (II.II\%) indicated "neither yes/no", one chose $(3.70 \%)$ "little", and six selected $(22.22 \%)$ "no" negative feelings caused by the switch to the Ukrainian version of their home city's name. Two participants $(6.70 \%)$ left this question blank (see Table 6).

\section{Street names}

Not only were the cities and towns of the study participants affected by change, but some of the streets they lived on were altered as well. Most of the participants reported preference for the Russian version of their street name $(82.60 \%$; $n=76$ ) compared to I5 respondents ( $16.30 \%$ ) who had no preference (and one questionnaire had no response to this question).

Of the 28 people whose streets were renamed, seven $(25 \%)$ reported "much" and nine $(32.14 \%)$ reported "some" inconvenience, while three (I0.72\%) marked the "neither yes/no" and nine (32.I4\%) reported "no" trouble/inconvenience. Among those who lived in a renamed street AND preferred its Russian name $(n=23)$, seven $(30.43 \%)$ claimed to have had "much" and eight $(34.79 \%)$ claimed "some" inconvenience caused by the change, while three respondents ( $\mathrm{I} 3.04 \%)$ chose the "neither yes/no" answer, and five (21.74\%) had "no" trouble (see Table 7).

Some people felt some irritation/negative emotions in connection to the renaming of their streets: "much" irritation for six participants $(2 \mathrm{I} .43 \%)$ out of the 28 who experienced it, and "some" for eight participants $(26.07 \%)$. Three respondents (I0.72\%) were ambivalent with a "neither yes/no" response, one $(3.57 \%)$ had "little" negative feelings, and ro $(35.7 \mathrm{r} \%)$ had "none". Of those who had their street renamed AND preferred its Russian name $(n=23)$, six $(26.08 \%)$ were "very" bothered by the renaming, seven $(30.44 \%)$ had "some" negative feelings; "neither yes/no" and "little" tallies remained the same ( $13.05 \%$ and $4.35 \%$, respectively), but the "none" score decreased to six $(26.08 \%)$ (see Table 6).

\section{Remaining in Russia vs returning home}

The last question of the survey inquired whether the participants planned to return to their homeland or to remain in Russia. Out of the 92 participants, I2 were unsure about their future and either left the options unmarked or circled both of them. Several people reported that they did not know what they will do, with one writing in "time will tell". Out of those who did share their intentions $(n=80), 60(75 \%)$ were planning to stay in the Russian Federation, and 20 $(25 \%)$ wanted to return to Ukraine. 
TABLE 8

RETURNING TO UKRAINE VS REMAINING IN RUSSIA

\begin{tabular}{|c|c|c|c|c|}
\hline & \multicolumn{2}{|c|}{ Returning to Ukraine $(n=20)$} & \multicolumn{2}{|c|}{ Remaining in Russia $(n=60)$} \\
\hline & $\begin{array}{l}\text { Very Much } \\
\text { or Some }\end{array}$ & $\begin{array}{c}\text { Neutral, Little, } \\
\text { None, No Response }\end{array}$ & $\begin{array}{l}\text { Very Much } \\
\text { or Some }\end{array}$ & $\begin{array}{c}\text { Neutral, Little, None, } \\
\text { No Response }\end{array}$ \\
\hline $\begin{array}{l}\text { Negative emotions caused } \\
\text { by changes to own names }\end{array}$ & 2 & 18 & 15 & 45 \\
\hline $\begin{array}{l}\text { Negative emotions caused } \\
\text { by changes to children's } \\
\text { names }\end{array}$ & 1 & 19 & 20 & 40 \\
\hline $\begin{array}{l}\text { Negative emotions caused } \\
\text { by lack of choice }\end{array}$ & 3 & 17 & 22 & 38 \\
\hline $\begin{array}{l}\text { Negative emotions caused } \\
\text { by changes to city names }\end{array}$ & 2 & 18 & 15 & 45 \\
\hline $\begin{array}{l}\text { Negative emotions caused } \\
\text { by renaming streets }\end{array}$ & 2 & 18 & 12 & 48 \\
\hline
\end{tabular}

Separating the questionnaires according to this factor and comparing the answers for the "stay" group with the responses of the "return" group produced some thought-provoking results. Those who were going to stay in Russia reported slightly higher levels of irritation by the administrative actions related to altering anthroponyms and toponyms.

Table 8 aggregates the numbers for the reported negative feeling evoked by Ukrainization of: (I) people's own names; (2) their children's names; (3) lack of choice in recording children's names in official documents; (4) renaming cities; and (5) renaming streets. Because the salient information in this case was some degree of irritation, whether high (as in "much" responses) or low to medium (as in "some"), those answers were combined in the table. The answers "neither yes nor no", "little", "none", or leaving the line blank was regarded as showing absence of negative emotions were also aggregated.

The difference between the "return" and "stay" groups is illustrated by the chart in Figure I, with absolute numbers turned into percentages since the groups being compared were unequal in size. The chart displays a higher level of negative emotions caused by the Ukrainization of the names among the members of the group who planned to remain in Russia. The biggest factors appear to be the changes in the names of respondents' children and the lack of parental choice in the recording of children's names according the norms of the language spoken by the parents.

To check whether the difference in the levels of negative emotions in the two groups (the "stay" group vs the "return" group) caused by renaming were statistically significant, the binomial test for proportions was applied. Again, the values for "much" and "some" were combined, however, the blanks were excluded, and the totals (20 for "return home" and 60 for "stay") were adjusted accordingly because some irrelevant questions were left unanswered. For example, the people whose names were not changed could not answer the question whether their name change caused any negative feelings. $P$-values calculated for each question are presented in Table 9, with those less than 0.05 in bold font. 


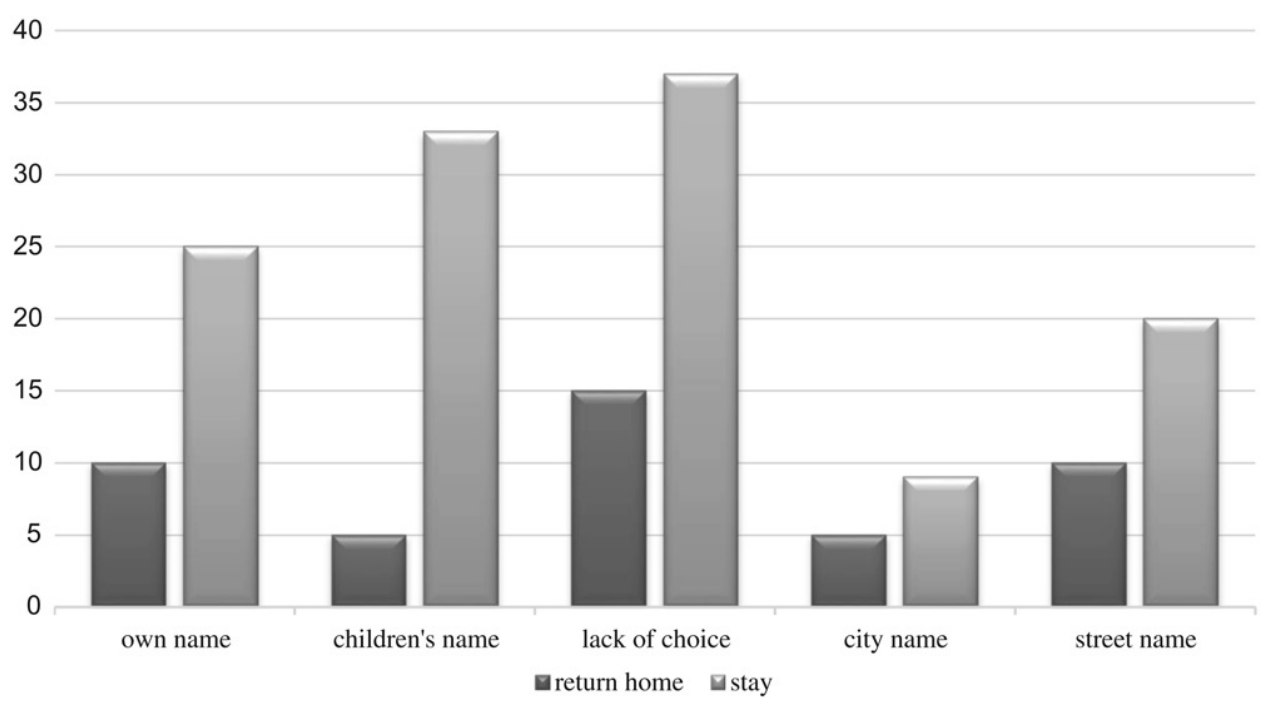

FIGURE 1. Reported negative emotions (\%) in "return" and "stay" groups.

TABLE 9

P-VALUES OF THE DIFFERENCES BETWEEN “RETURN" AND "STAY” GROUPS

\begin{tabular}{lcccc}
\hline Own Name & Children's Name & Lack of Choice & City Name & Street Name \\
\hline 0.105338 & $\mathbf{0 . 0 0 4 8 0 8}$ & $\mathbf{0 . 0 3 2 6 7 5}$ & $\mathbf{0 . 0 3 0 3 9 4}$ & 0.095173 \\
\hline
\end{tabular}

The results related to the Ukrainization of children's names, lack of choice for recording children's names according to the parents' preference, and city name changes proved to be statistically significant at the $95 \%$ confidence level $(p<$ $0.05)$. Thus, there appears to be a correlation between the choice to remain in Russia vs returning to Ukraine and the level of irritation caused by the Ukrainization of names of respondents' children and of toponyms. The connection between the negative feelings reported with regard to the Ukrainization of the names of the streets the people live on and of their own names is weaker: the former is only statistically significant at the $90 \%$ confidence level $(p<0.10)$, and the latter only close to it. Therefore, it is impossible to claim with certainty that those trends are not accidental.

\section{Discussion}

The results of this study contribute to a better understanding of a topic that has not received a great deal of attention in linguistic research. Stringent onomastic practices aiming to erase ethnic differences in favor of national homogeneity, such as renaming Turks in Bulgaria (Davies and Dubinsky forthcoming), Slavs in Mussolini's Italy (Hametz 20I2), Ainu in Japan (Irish 2009), Kurds in Turkey (Aslan 2009), and Native Americans in the US and Canada (Littlefield and 
Underhill I97I; Scott, Tehranian, and Mathias 2002) have been described in the scholarly literature. These sources, however, rely mostly on historical or sociological data rather than on direct polling of the affected citizenry. The survey conducted among Ukrainian refugees is different from those sources in its experimental nature.

It has been noted that heavy-handed naming policies can sometimes backfire and lead to unintended consequences, such as resistance or a revival of ethnic pride and revitalization of the very customs and traditions the authorities were aiming to eliminate (Aslan 2009; Zhelyazkova 200I). In the group polled, the process of top-down Ukrainization of Russian anthroponyms and toponyms appeared to cause some resentment even though it was lower than in the cases of Kurds in Turkey (Aslan 2009) or Turks in Bulgaria (Zhelyazkova 200I). Most participants reported using proper names in the language of their preference without much trouble before the beginning of the war. Nevertheless, the survey revealed at least some negative attitudes, especially related to adjustments to the respondents' own names and to the names of their children. The practice that caused the most discontent was forced Ukrainization of children's names, with government agencies modifying names to conform to the Ukrainian norms and disregarding parents' preferences.

The renaming of cities and streets did not produce as much resentment even though that practice also caused some inconvenience and prompted some negative attitudes. A possible explanation for this difference is the lower level of connection a person has with the name of a street or a city than with his/her own name and the names of his/her children: a person's name is perceived as belonging only one person while a city is shared by multitudes. Also, in Russian/Ukrainian culture, a name is typically kept throughout one's life, but street and city affiliation can change several times during a lifetime.

Although the data does not prove a cause and effect relationship, there appears to be a relationship between the choice to remain in Russia vs returning to Ukraine with the level of irritation caused by Ukrainization reported by the respondents. While it is reasonable to assume that the main factor in the respondents' decision to stay in Russia or to return home was their safety, those who expressed an intention to return to Ukraine were less likely and those who planned to stay in the Russian Federation were more likely to report some negative feelings caused by the Ukrainization of proper names. The differences between the two groups were statistically significant for the levels of negative emotions caused by the Ukrainization of children's names, by the lack of choice in recording children's names in official documents, and by the renaming of cities.

\section{Conclusions and future research}

The project confirmed the importance of the freedom to use proper names in a person's first language. The rigid policy of Ukrainization that goes as far as infringing on parents' control over naming their children in accordance with the language they use in the family did appear to cause some resentment in the group polled. 
Nevertheless, the results of the study should be regarded with caution. The project's generalizability is undoubtedly limited by the small number of participants. It is also affected by the special nature of the cohort surveyed: refugees, traumatized by the war in their homeland, who were forced to escape and seek shelter in a foreign country, may not be representative of the majority of the population of southeast Ukraine, let alone the other Ukrainian territories. Because of this, one should not draw far-reaching conclusions based on the results of this survey. It would be better to view this investigation as a pilot aimed at stimulating discussion, drawing attention to the sociolinguistic processes in Ukraine, and encouraging researchers to evaluate the effects of those processes on the population. Ideally, it should be critiqued and replicated on a larger scale and/or with different cohorts of respondents.

At the same time, the trends revealed by the study should not be dismissed. The unintended consequences of the official linguistic ideology warrant scholarly attention, and the results of such research may be of use not only to sociolinguists and onomasiologists but also to policymakers. If, indeed, the heavyhanded Ukrainization of eastern Ukraine contributes to distancing its inhabitants from the current political developments in the country, Ukraine could benefit from "embracing the Russian language and culture as legitimate aspects of Ukrainian identity' and moving "toward the inclusive civic patriotism" (Petro 20I 5, 32-33). If the Ukrainization that has replaced Russification causes inconvenience and negative feelings among the affected population, it may endanger social progress at a time when unity and agreement are most needed.

\section{Notes}

I. For an in-depth overview, see Bilaniuk (2005) or Pavlenko (2008).

2. For a history of the Russian-Ukrainian interaction and a discussion of the current linguistic ideology, see Friedman (2009).

3. Translations in this paper are provided by the author. The style has been preserved as much as possible, and idiomatic expressions were translated as closely to the original as was feasible. Some content necessary for understanding is included in square brackets, and code-switching between Russian and Ukrainian is marked in bold face.

4. A shorter version of this paper was presented at the American Name Society conference held in conjunction with the Linguistics Society of America (LSA), JW Marriott, Austin, TX, January 5,2017 .

\section{Disclosure statement}

No potential conflict of interest was reported by the author.

\section{Bibliography}

A'Beckett, Ludmilla. 20I3. "Restoring the Functional Domains of a Formerly 'Oppressed' Language: The Pitfalls of Promoting Ukrainian for Ukrainians." Annual of Language and Politics and Politics of Identity 7 , no. I: $23-47$.

Andreenkova, Anna. 20I4. "Which Language Should We Use for Interview in Multi-Linguistic Environment." http://www.aapor.org/AAPOR_Main/media/AnnualMeetingProceedings/20I4/Session-E-I-I-Andreenkova-Y.pdf 
Aslan, Senem. 2009. "Incoherent State: The Controversy over Kurdish Naming in Turkey.” European Journal of Turkish Studies [Online], no. Io. http://journals.openedition.org/ejts/4I42.

Bilaniuk, Laada. 2005. Contested Tongues: Language Politics and Cultural Correction in Ukraine. London: Cornell University Press.

Bilaniuk, Laada, and Svitlana Melnyk. 2008. "A Tense and Shifting Balance: Bilingualism and Education in Ukraine." International Journal of Bilingual Education and Bilingualism I I, no. 3-4: 340-72.

Davies, William D. and Stanley Dubinsky. forthcoming. "Chapter 5: Language and Personal Identity Personal Names in the World." In Language Conflict and Language Rights: Ethnolinguistic Perspectives on Human Conflict. Cambridge: Cambridge University Press.

Friedman, Debra A. 2009. "Speaking Correctly: Error Correction as a Language Socialization Practice in a Ukrainian Classroom." Applied Linguistics 3 I, no. 3: 346-67.

Giddens, Anthony. I99I. Modernity and Self-Identity: Self and Society in the Late Modern Age. Cambridge: Polity.

Gradirovski, Sergei and Neli Esipova. 2008. "Russian Language Enjoying a Boost in Post-Soviet States." Gallup. http://www.gallup.com/poll/ı09228/Russian-Language-Enjoying-Boost-PostSoviet-States.aspx

Gross, Aeyal M. I996. "Rights and Normalization: A Critical Study of European Human Rights Case Law on the Choice and Change of Names." Harvard Human Rights Journal 9: 269-84.

Hametz, Maura E. 2012. In the Name of Italy: Nation, Family, and Patriotism in a Fascist Court. New York: Fordham University Press.

Interfax-Ukraine. 2015, Oct. 26. "77\% of Kirovograd Residents Favor Return of City"s Name of Yelisavetgrad - Media." http://en.interfax.com.ua/news/general/299070.html

Irish, Ann B. 2009. Hokkaido: A History of Ethnic Transition and Development on Japan"s Northern Island. Jefferson, NC: McFarland and Company.

Jernudd, Bjorn H. 20I0. "Personal Names and Human Rights." In Linguistic Human Rights: Overcoming Linguistic Discrimination, edited by T. Skutnabb-Kangas and R. Phillipson, I2 I-32. Berlin: Mouton de Gruyter.

Joseph, Sarah, and Melissa Castan. 2013. The International Covenant on Civil and Political Rights: Cases, Materials, and Commentary. 3 rd ed. Oxford: Oxford University Press.

Kontra, Miklos. I999. "Some Reflections on the Nature of Language and Its Regulation." International Journal on Minority and Group Rights 6, no. 3: 28I-8. doi:Io.I I63/I 57 I 8I I 9920907730.

Le Page, Robert B., and Andree Tabouret-Keller. 1985. Acts of Identity: Creole-Based Approaches to Language and Ethnicity. Cambridge: Cambridge University Press.

Littlefield, Daniel F., and Lonnie E. Underhill. I97I. "Renaming the American Indian: I890-I9I3." American Studies I 2, no. 2: 33-45.

OSCE. I998. "The Oslo Recommendations regarding the Linguistic Rights of National Minorities \& Explanatory Note." http://www.osce.org/hcnm/6753 I ?download=true

Pavlenko, Aneta. 2008. "Multilingualism in Post-Soviet Countries: Language Revival, Language Removal, and Sociolinguistic Theory." International Journal of Bilingual Education and Bilingualism II, no. 3-4: 275-3I4.

Petro, Nicolai N. 2015. "Understanding the Other Ukraine: Identity and Allegiance in Russophone Ukraine." In Ukraine and Russia: People, Politics, Propaganda and Perspectives, edited by Richard Sakwa and Agnieszka Pikulicka-Wilczewska, I9-35. Bristol, United Kingdom: E-International Relations Edited Collections.

Pogrebinskiy, Mikhail. 20I 5. "Russians in Ukraine: Before and after Euromaidan.” In Ukraine and Russia: People, Politics, Propaganda and Perspectives, edited by Richard Sakwa and Agnieszka PikulickaWilczewska, 90-9. Bristol, United Kingdom: E-International Relations Edited Collections.

Polese, Abel, and Anna Wylegala. 2008. "Odessa and Lvov or Odesa and Lviv: How Important is a Letter? Reflections on the "Other" in Two Ukrainian Cities." Nationalities Papers 36, no. 5: 787-8 I4.

Politota [Политота]. 2ог4. “Фарион Проводит Украинизацию в Детском Саду [Farion is Conducting Ukrainization in a Kindergarten].” [YouTube Video in Ukrainian]. https://www.youtube.com/watch?v= 5 IOBHZMLMyQ

Sakwa, Richard. 20I6. Frontline Ukraine: Crisis in the Borderlands. London and New York: I. B. Tauris.

Scott, James C., John Tehranian, and Jeremy Mathias. 2002. "The Production of Legal Identities Proper to States: The Case of the Permanent Family Surname." Comparative Studies in Society and History 44, no. I: $4-44$.

Skutnabb-Kangas, Tove. I98I. Bilingualism or Not: The Education of Minorities. Clevedon, Avon: Multilingual Matters. 
Skutnabb-Kangas, Tove. 2000. Linguistic Genocide in Education-or Worldwide Diversity and Human Rights?. Mahwah, NJ: Routledge.

Wilson, Andrew. 2002. "Elements of a Theory of Ukrainian Ethno-National Identities." Nations and Nationalism 8, no. I: 3 I-54.

Zhelyazkova, Antonina. 200I. "The Bulgarian Ethnic Model." East European Constitutional Review ro, no. $4: 62-6$.

\section{Notes on contributor}

Natalia Knoblock is an Assistant Professor of English at the Saginaw Valley State University. Her research interests lie mostly in political linguistics, sociolinguistics, and discourse analysis. Some of her work focused on the US presidential debates, xenophobia and aggression in online communication, as well as insults and propaganda. (D) http://orcid.org/0000-0002-0684-3055

Correspondence to: Natalia Knoblock, Saginaw Valley State University, 7400 Bay Road, University Center, MI 487ı。, USA. Email: nlknoblo@svsu.edu 